\title{
Analisis Indeks Trombosit dan Rasio Trombosit Limfosit sebagai Penanda Kerusakan Ginjal pada Penderita Hipertensi Berbagai Derajat
}

\author{
Analysis Platelet Indices and Platelet Lymfosit Ratio as A Kidney Damage Marker in Degree of \\ Hypertensi
}

\author{
Nelly Tolla ${ }^{1}$, Nurdin Perdana ${ }^{2}$, Salsa Anggeraini ${ }^{3}$, Nur Faidah ${ }^{4}$ \\ ${ }^{1}$ Bagian Biomedik Fisiologi FK Universitas Muhammadiyah Makassar \\ ${ }^{2}$ Bagian Keselamatan Kerja FK Universitas Muhammadiyah Makassar \\ ${ }^{3}$ Bagian Biomedik Mikrobiologi FK Universitas Muhammadiyah Makassar \\ ${ }^{4}$ Bagian Biomedik Biokimia FK Universitas Muhammadiyah Makassar \\ *Penulis koresponesi: Nelly Tolla. Email: nellymashuri@gmail.com
}

\begin{abstract}
ABSTRAK
Latar Belakang: Hipertensi merupakan salah satu faktor risiko terjadinya kematian dini dan penyakit kardiovaskular yang menyebabkan setidaknya 1,1 juta kematian per tahun di dunia. Hipertensi merupakan penyakit yang sering kali dijumpai tanpa gejala, sering menimbulkan berbagai komplikasi seperti stroke, penyakit jantung dan pembuluh darah, penyakit ginjal dan lainnya yang pada akhirnya dapat mengakibatkan kecacatan maupun kematian bila tidak diobati dan dikenal dengan istilah The Silent Killer. Hipertensi meningkatkan stres dinding pembuluh darah yang akan memulai terjadinya hipertrofi dan hiperplasia otot polos vascular, selain itu, hipertensi dapat menimbulkan kerusakan endotel yang memungkinkan penetrasi lipoprotein ke dalam dinding vascular yang dapat memudahkan terjadinya aterosklerosis. Disfungsi endotel secara tidak langsung mempengaruhi fungsi trombosit yang berperan dalam membentuk sumbatan atau yang dikenal dengan plug primer. Pembentukan plug primer dipengaruhi oleh jumlah dan fungsi trombosit yang dapat dianalisa berdasarkan indeks trombosit yaitu Mean Platelet Volume (MPV), Platelet Distribution Width (PDW), Plateletcrit (PCT) dan rasio trombosit limfosit (RTL). ${ }^{2,6,7}$

Metode: Penelitian ini menggunakan rancangan cross sectional dan penyajian data dalam bentuk deskriptif analitik. Seratus tujuh puluh penderita hipertensi dikelompokkan menjadi kelompok stadium hipertensi 1, 2 dan 3 . Indeks trombosit yaitu Mean Platelet Volume (MPV), Platelet Distribution Width (PDW) dan Plateletcrit (PCT) dan rasio trombosit limfosit (RTL) dihitung berdasarkan hasil pemeriksaan darah rutin. Distribusi data diuji dengan KolmogrovSmirnov dan dianalisa dengan uji data yang sesuai.

Hasil: Berdasarkan uji analisa statistik one way Anova, indeks trombosit yaitu MPV pada penderita hipertensi berbeda bermakna pada setiap derajat hipertensi, dengan masing-masing mean dan standar deviasi, derajat $1(8.92 \pm 1.23)$, derajat $2(8.99 \pm 1.63)$ dan derajat $3(11.2 \pm 4.29)$ dengan nilai $\mathrm{p}=0.003$. Adanya korelasi yang lemah antara MPV dan kadar ureum kreatinin serum. Berdasarkan uji korelasi Pearson. Akan tetapi dalam penelitian ini, nilai PDW dan RTL hanya berkorelasi dengan kreatinin.
\end{abstract}

Kesimpulan: Terdapat perbedaan nilai MPV pada penderita hipertensi berbagai derajat. Adanya korelasi antara nilai MPV,PDW dan RTL dan kreatinin yang menunjukkan adanya penanda kerusakan pada ginjal.

Kata kunci: Hipertensi, indeks trombosit(MPV,PDW dan PCT) dan rasio trombosit limfosit.

\section{ABSTRACT}

Background: Hypertension is a risk factor for early death and cardiovascular disease which causes at least 1.1 million deaths per year in the world. Hypertension is a disease that is often found without symptoms, causing various complications such as stroke, heart and blood vessel disease, kidney disease and others which can ultimately lead to disability or death if left untreated and known as The Silent Killer. Hypertension increases blood vessel wall stress which will initiate hypertension and vascular smooth muscle hyperplasia. In addition, hypertension accelerates the process of atherosclerosis by causing endothelial damage which allows penetration of lipoproteins into the vascular wall. Endothelial dysfunction indirectly affects the function of platelets which play a role in forming the blockage or what is known as the primary plug. The formation of a primary plug is influenced by the number and function of platelets which can be assessed based on the platelet index namely Mean Platelet Volume (MPV). Platelet Distribution Width (PDW) and Plateletcrit PCT) and platelet lymphocyte ratio (PLR). 2,6,7

Method: This study used a cross sectional design and presentation of data in a descriptive analytic form. One hundred and seventy patients with hypertension were grouped into hypertensive stage groups 1, 2 and 3. Mean Platelet Volume 
(MPV), Platelet Distribution Width (PDW) and Plateletcrit (PCT) and lymphocyte platelet ratio were calculated based on the results of routine blood tests. Data distribution was tested by Kolmogrov-Smirnov and analyzed with the corresponding data test.

Results: Based on the one way Anova statistical analysis test, the platelet index of MPV in hypertensive patients was significantly different at each degree of hypertension, with each mean and standard deviation, grade 1 (8.92 \pm 1.23$)$, degree $2(8.99 \pm 1.63)$ and degree $3(11.2 \pm 4.29)$ with a value of $p=0.003$. There was a weak correlation between MPV and serum creatinine ureum levels based on the Pearson correlation test. However, in this study, PDW and PLR values only correlated with creatinine.

Conclusion: There are differences in the value of MPV in patients with hypertension of various degrees. There is a correlation between the values of MPV, PDW and PLR and creatinine which indicate a marker of damage to the kidneys.

Keywords: Hypertension, platelet index (MPV, PDW and PCT) and platelet lymphocyte ratio.

\section{PENDAHULUAN}

Hipertensi (HT) atau tekanan darah tinggi merupakan suatu keadaan yang menggambarkan peningkatan tekanan darah sistolik lebih dari $140 \mathrm{mmHg}$ dan atau diastolik lebih dari $90 \mathrm{mmHg}$ pada dua kali pengukuran dengan selang waktu 5 menit dalam keadaan istirahat (tenang). Hipertensi merupakan faktor risiko utama terjadinya kematian dini dan penyakit kardiovaskular (CVD), yang menyebabkan setidaknya 1,1 juta kematian per tahun di dunia. ${ }^{1-3}$

Data World Health Organization (WHO) 2013 melaporkan sekitar 1,13 miliar orang di dunia menderita hipertensi yang setiap tahunnya terus meningkat dan diperkirakan mencapai 1,5 miliar orang pada tahun 2025 . Menurut hasil Riskesdas tahun 2013 prevalensi hipertensi di Sulawesi Selatan berdasarkan umur $\geq 18$ tahun sebesar 28,1 persen, tertinggi di Enrekang (31,3\%), diikuti Bulukumba (30,8\%), Sinjai $(30,4 \%)$ dan Gowa $(29,2 \%) .^{4-5}$

Hipertensi dikenal dengan istilah The Silent Killer sehubungan dengan umumnya pasien datang dengan tanpa gejala, yang sering menimbulkan komplikasi seperti stroke, penyakit jantung dan pembuluh darah, gangguan ginjal dan lainnya jika tidak diobati dan ditanggulangi yang pada akhirnya dapat mengakibatkan kecacatan maupun kematian. Keadaan prothrombotik pada hipertensi didukung oleh sejumlah faktor lain seperti kerusakan endotel dan aterosklerosis memberikan sifat prokoagulan ke endotel pembuluh darah. Disfungsi endotel memicu reaktivitas trombosit melalui peningkatan pembentukan trombosit dan aktivitas trombosit sebagai indikasi adanya inflamasi sistemik termasuk inflamasi glomerulus. Disfungsi endotel secara tidak langsung mempengaruhi disfungsi trombosit yang dapat dinilai berdasarkan indeks trombosit dan rasio trombosit limfosit. ${ }^{2,6,7}$

Dalam keadaan fisiologis, trombosit yang bersirkulasi dalam pembuluh darah intak mencegah interaksi dan perlekatan dengan sel lain serta aktivasi trombosit dengan memproduksi bahan antitrombotik seperti prostasiklin, nitric oxide (NO), ekspresi ectoADPase. Adanya faktor risiko termasuk merokok, diabetes, hipertensi, kadar LDL yang tinggi, tekanan tinggi pada stenosis arteri, vasoaktif amine, radikal bebas dan infeksi mikroorganisme menyebabkan kerusakan endotel. Disfungsi endotel yang ditandai dengan penurunan bioavaibilitas NO, mencetuskan serangkaian proses pembentukan lesi aterosklerosis. Jalur NO memliki interaksi sinergistik dengan pembentukan/degradasi nukleotida siklik dan fosforilasi protein pada trombosit dan sel otot polos, yang mengatur fungsi kardiovaskular (tonus vaskular, inhibisi agregasi trombosit serta adhesi leukosit, dan pencegahan proliferasi sel otot polos). ${ }^{8-10}$ 
Dalam beberapa tahun terakhir, neutrofilia dan lymphocytopenia relatif terbukti menjadi prediktor independen kematian pada pasien dengan gagal jantung akut. Selain itu, rasio neutrofil-ke-limfosit (NLR) diperkenalkan sebagai penanda potensial untuk menentukan inflamasi pada gangguan jantung dan nonjantung. Selain itu, NLR ditunjukkan sebagai prediktor mortalitas jangka panjang pada pasien yang menjalani intervensi koroner perkutan.

\section{TUJUAN}

Untuk menganalisis nilai indeks trombosit dan rasio trombosit limfosit sebagai penanda kerusakan ginjal pada penderita hipertensi.

\section{METODE}

Penelitian ini dilakukan secara Cross Sectional dengan observasional analitic dengan mengambil dan mengumpulkan data penderita hipertensi periode Maret - Juli 2019 di RSUP dr. Wahidin Sudirohusodo Makassar

Kriteria inklusi adalah pasien hipertensi yang telah terdiagnosis oleh klinisi yang memiliki data rekam medik lengkap seperti usia, riwayat penyakit dan terapi. Pasien yang menderita hipertensi disertai gagal ginjal, gagal jantung dan penyakit autoimun akan dieksklusi dari penelitian. Pasien yang memenuhi kriteria inklusi akan dilakukan vena punksi dan ditampung dalam 2 tabung yaitu tabung tanpa antikoagulan untuk pemeriksaan ureum kreatinin diperiksa dengan menggunakan metode enzimatik kolorimetrik dan antikoagulan EDTA untuk pemeriksaan darah rutin dengan mengambil hasil indeks trombosit (MPV, PDW dan PCT) dan rasio trombosit limfosit dengan menggunakan hasil pemeriksaan darah rutin dengan metode flowcytometry. Pasien hipertensi dikelompokkan menjadi 3 kelompok berdasarkan derajat hipertensi 1, 2 dan 3 berdasarkan hasil pengukuran tekanan darah dengan menggunakan stetoskop dan sphymometer.

\section{HASIL DAN PEMBAHASAN \\ Hasil}

Penelitian dilakukan selama 3 bulan dengan jumlah sampel 170 penderita yang terdiri dari 84 orang laki-laki dan 86 responden perempuan dengan umur terbanyak menderita hipertensi berkisar pada umur 5556 tahun (Tabel 1).

Uji oneway Anova menunjukkan terdapat perbedaan bermakna antara nilai MPV pada hipertensi derajat 1,2 dan 3 dengan nilai $\mathrm{p}<0.05$ dan kelompok DM tipe 2 tidak ada perbedaan bermakna antara PDW dan PCT pada hipertensi pada derajat 1,2 dan 3 (Tabel 2).

Uji oneway Anova menunjukkan tidak ada perbedaan bermakna antara nilai RTL pada semua kelompok derajat hipertensi $(p>0.05)$ (Tabel 3).

Dengan uji Spearman rho menunjukkan adanya hubungan antara nilai Ureum dan kreatinin dengan nilai MPV pada penderita hipertensi dengan kekuatan korelasi rendah $(\mathrm{p}<0.05, \quad \mathrm{r}<0.05)$. Nilai PDW dan kadar kreatinin juga menunjukkan adanya dengan nilai $\mathrm{p}<0.01$ dengan kekuatan korelasi rendah r <0.05 (Tabel 4).

Dengan uji Spearman rho menunjukkan adanya hubungan negative antara nilai kreatinin dengan nilai RTL pada penderita hipertensi dengan kekuatan korelasi rendah ( $\mathrm{r}$ $<0.50)$ (Tabel 5). 


\section{Pembahasan}

Penelitian ini dilakukan pada bulan Juli sampai Agustus 2017 dengan mengambil data rekam medik periode Maret - Juli 2019 di RS.dr. Wahidin Sudirohusodo. Penelitian ini menggunakan desain penelitian cross sectional metode observasional analitik dengan melibatkan 170 responden yang memenuhi kriteria inklusi. Perempuan lebih banyak menderita Hipertensi dibandingkan laki-laki pada kelompok umur 55-60 tahun.

Penelitian ini sejalan dengan penelitian yang dilakukan oleh Cortas, 2008 menyatakan bahwa angka kejadian hipertensi pada pria sama dengan wanita, hal ini dianggap bahwa wanita yang telah memasuki masa menopause mengalami penurunan kadar estrogen. Hormon estrogen berperan dalam meningkatkan kadar High Density Lipoprotein (HDL). Kadar kolesterol HDL yang tinggi merupakan faktor pelindung dalam mencegah terjadinya proses aterosklerosis yang memicu peningkatan tekanan darah. Hal ini tidak sejalan dengan penelitian yang dilakukan oleh Kusumawaty, 2016 bahwa jumlah penderita hipertensi lebih banyak pada perempuan (55\%) dibandingkan dengan laki-laki (45\%) meskipun frekuensi laki-laki yang mengalami hipertensi ringan lebih besar daripada perempuan. ${ }^{11,12}$

Uji oneway Anova, menunjukkan adanya perbedaan bermakna antara nilai indeks trombosit yaitu MPV pada pasien hipertensi berbagai derajat. Mean Platelet Volume menggambarkan ukuran rata-rata trombosit sebagai penanda aktivitas trombosit. Kerusakan endotel menyebabkan terjadinya perubahan morfologi dan fungsi trombosit dibandingkan endotel yang masih intak. Hipertensi dapat bermanifestasi pada disfungsi endotel, akibatnya trombosit akan teraktivasi dan mengekspresikan lebih banyak P-Selektin dan reseptor GP IIb/IIIa sehingga lebih sensitif terhadap rangsangan zat-zat agonis dibandingkan dengan trombosit pada pasien non hipertensi . ${ }^{7,8}$

Pada penelitian ini, nilai PDW pada penderita hipertensi menunjukkan nilai $\mathrm{P}>0.05$ yang berarti tidak ada perbedaan bermakna. Parameter PDW adalah penanda sederhana dan praktis serta spesifik dari aktivasi koagulasi yang digunakan untuk menentukan heterogenitas ukuran trombosit. Hiperaktivitas trombosit ditandai dengan perubahan morfologi trombosit menjadi bentuk sferis dan pembentukan pseudopodia serta meningkatnya jumlah trombosit muda (megakariosit) yang dilepaskan ke pembuluh darah perifer dengan ukuran yang lebih besar, lebih reaktif dan aggregable. Megakariosit berisi granula yang lebih besar dan padat, kadar serotonin dan $\beta$ thromboglobulin lebih tinggi, serta menghasilkan tromboksan A2 yang lebih banyak dibandingkan trombosit matur. Hal ini menyebabkan ukuran trombosit menjadi lebih bervariasi yang digambarkan dengan peningkatan penanda indeks trombosit lainnya yaitu PDW. ${ }^{9,12}$

Beberapa pendapat mengemukakan bahwa parameter indeks trombosit seperti MPV dan PDW dan jumlah trombosit tidak dapat dipisahkan sebagai indikator aktivitas trombosit. Banyak peneliti telah menggambarkan bahwa trombosit menempati posisi penting dalam memediasi respon imun dan mempertahankan homeostasis vaskular, aterosklerosis, dan peradangan. Penilaian indeks trombosit dan bioaktivitasnya mungkin sangat penting untuk memantau kejadian dan perkembangan hipertensi. ${ }^{13,14}$

Pada penelitian ini tidak ditemukan adanya perbedaan antara nilai PCT pada pasien hipertensi semua derajat. Hal ini sejalan dengan penelitian yang dilakukan oleh Kun Yang dkk, 2016 di Beijing. Peningkatan PCT 
diduga diawali dengan perubahan trombosit menjadi lebih besar dan lebih reaktif diikuti dengan peningkatan jumlah trombosit akibat konsumsi trombosit yang meningkat sehingga nilai PCT akan ikut meningkat. Akan tetapi pada penelitian ini tidak menunjukkan adanya perubahan PCT yang signifikan pada semua derajat hipertensi. ${ }^{9,15}$

Penelitian ini juga menemukan adanya korelasi antara kadar ureum kreatinin dengan nilai MPV dan PDW dengan $\mathrm{p}<0.05$ dengan nilai korelasi yang lemah. Pemeriksaan fungsi ginjal berupa ureum dan kreatinin merupakan salah satu pemeriksaan penunjang untuk mendeteksi adanya kerusakan pada ginjal sebagai salah satu komplikasi hipertensi. Trombosit memiliki peranan penting dalam hemostasis primer. Respon untuk memperbaiki kerusakan endotel, platelet berubah bentuk, menempel pada endotel dan melepaskan organel intasel serta beragregasi dan membentuk thrombus. Hal ini yang mengakibatkan terjadi peningkatan PDW. Penelitian ini membutuhkan telaah lebih lanjut untuk melihat apakah keadaan hiperglikemik dapat menurunkan aktivitas trombosit sehingga dapat mencegah atau menunda kemungkinan komplikasi vaskular diabetes.

Tabel 1. Karakteristik Penderita Hipertensi

\begin{tabular}{llll}
\hline Parameter & $\mathrm{N} /(\mathrm{Mean} \pm \mathrm{SD})$ & Min-Max & P value \\
\hline Jenis Kelamin & & & \\
Laki-laki & $84(49.4 \%)$ & & 0.000 \\
$\begin{array}{l}\text { Perempuan } \\
\text { Umur (Tahun) }\end{array}$ & $56(50.6 \%)$ & & 0.000 \\
Ureum (mg/dl) & $62.20 \pm 49.64$ & $11-198$ & 0.000 \\
Kreatinin (mg/dl) & $2.23 \pm 1.86$ & $0.40-9.79$ & $* 0.200$ \\
$\begin{array}{l}\text { Trombosit } \\
\left.\text { (10 }{ }^{3} / \mathrm{uL}\right)\end{array}$ & $281.85 \pm 119.15$ & $32-689$ & $* 0.069$ \\
Limfosit & $22.09 \pm 10.87$ & $1.90-47.80$ & 0.000 \\
MPV (fL) & $9.38 \pm 6.15$ & $0.00-86.00$ & 0.000 \\
PDW (fL) & $12.68 \pm 11.42$ & $0.00-155$ & 0.000 \\
PCT (\%) & $0.207 \pm 0.77$ & $0.28 \pm 0.14$ & 0.000 \\
$\begin{array}{l}\text { Rasio trombosit } \\
\text { limfosit }\end{array}$ & $0.207 \pm 0.767$ & $0.00-9.90$ & \\
\hline
\end{tabular}

Keterangan: Mean Platelet Volume (MPV), Platelet Distribution Width(PDW), Plateletcrit(PCT), P-Value (Mean \pm SD)

* Distribusi data normal ( $\mathrm{P}>0.05)$

Distribusi data normal pada kelompok trombosit dan limfosit 
Tabel 2. Analisis Perbedaan Nilai MPV pada Hipertensi Berdasarkan Stadium Hipertensi

\begin{tabular}{|c|c|c|c|c|}
\hline \multirow{4}{*}{ Parameter } & \multicolumn{3}{|c|}{$\mathrm{N} /($ Mean $\pm \mathrm{SD})$} & \multirow{4}{*}{$\mathrm{P}$ value } \\
\hline & \multicolumn{3}{|c|}{ Median (min-max) } & \\
\hline & \multicolumn{3}{|c|}{ Derajat Hipertensi } & \\
\hline & $\mathrm{I}$ & II & III & \\
\hline \multirow[t]{2}{*}{ MPV } & $8.92 \pm 1.23 /$ & $8.99 \pm 1.63 /$ & $11.2 \pm 4.29 /$ & \\
\hline & $6.8(0.00-8.3)$ & $8.8(0.00-11.3)$ & $9.1(6.9-11.10)$ & $* 0.003$ \\
\hline \multirow[t]{2}{*}{ PDW } & $13.09 \pm 12.89 /$ & $11.06 \pm 2.82 /$ & $12.01 \pm 3.24 /$ & \\
\hline & $11.7(0.00-155)$ & $11.5(0.00-16.4)$ & $11.1(7.7-18.5)$ & 0.069 \\
\hline \multirow[t]{2}{*}{ PCT } & $0.22 \pm 0.87 /$ & $0.14 \pm 0.15 /$ & $0.14 \pm 0.16 /$ & \multirow{2}{*}{0.073} \\
\hline & $0.16(0.00-9.90)$ & $0.14(0.00-0.47)$ & $0.04(0.00-0.42)$ & \\
\hline
\end{tabular}

Keterangan : SD: Standar Deviasi. *one way Anova. MPV: Mean Platelet Volume (nilai normal 6.5 - 11 (fL ), PDW : Platelet Distribution Width $(10-18 \mathrm{fl}), \mathrm{PCT}$ : Plateletcrit $(0.15-0.50 \%)$

Tabel 3. Perbedaan nilai Rasio trombosit limfosit (RTL) pada hipertensi berbagai derajat

\begin{tabular}{|c|c|c|c|c|}
\hline \multirow{4}{*}{ Parameter } & \multicolumn{3}{|c|}{ N/(Mean \pm SD) } & \multirow{4}{*}{$P$ value } \\
\hline & \multicolumn{3}{|c|}{ Median (min-max) } & \\
\hline & \multicolumn{3}{|c|}{ Derajat Hipertensi } & \\
\hline & $\mathrm{I}$ & II & III & \\
\hline RTL & $\begin{array}{l}19.92 \pm 26.75 / \\
12.3(2.00-153.6)\end{array}$ & $\begin{array}{l}23.81 \pm 25.97 / \\
11.8(1.30-119.3)\end{array}$ & $\begin{array}{l}23.3 \pm 26.37 / \\
18(2.40-90.10)\end{array}$ & 0.078 \\
\hline
\end{tabular}

Keterangan : SD: Standar Deviasi. *one way Anova. MPV : Mean Platelet Volume (nilai normal 6.5 - 11 (fL ), PDW : Platelet Distribution Width $(10-18 \mathrm{fl})$, PCT : Plateletcrit $(0.15-0.50 \%)$

Tabel 4. Analisis Hubungan antara Ureum Kreatinin dengan Indeks Trombosit pada Hipertensi

\begin{tabular}{lllllll}
\hline \multirow{2}{*}{ Parameter } & MPV & \multicolumn{3}{c}{ PDW } & \multicolumn{3}{l}{ PCT } \\
\cline { 2 - 7 } & $\mathrm{r}$ & $\mathrm{P}$ & $\mathrm{r}$ & $\mathrm{p}$ & $\mathrm{r}$ & $\mathrm{P}$ \\
\hline Ureum & 0.292 & $* 0.049$ & 0.264 & 0.086 & 0.330 & 0.075 \\
Kreatinin & 0.345 & $* 0.016$ & 0.176 & $* 0.010$ & 0.247 & 0.089
\end{tabular}

Keterangan: $r$ : korelasi, P value:gambaran Mean $+\mathrm{SD},{ }^{*} \mathrm{r}:$ kekuatan korelasi, Spearman rho

Tabel 5. Analisis Hubungan antara Ureum Kreatinin dengan Rasio Trombosit Limfosit pada Hipertensi

\begin{tabular}{cccccc}
\hline \multirow{2}{*}{ Parameter } & \multicolumn{2}{c}{ Ureum } & \multicolumn{2}{c}{ Kreatinin } \\
\cline { 2 - 5 } & $\mathrm{r}$ & $\mathrm{p}$ & $\mathrm{r}$ & $\mathrm{p}$ \\
\hline RTL & -0.123 & & 0.109 & -0.173 & $* 0.024$
\end{tabular}

Keterangan : r : korelasi, P value:gambaran Mean $+\mathrm{SD},{ }^{*} \mathrm{r}:$ kekuatan korelasi, Spearman rho 


\section{KESIMPULAN}

Adanya perbedaan rerata nilai indeks trombosit yaitu MPV pada penderita hipertensi yang tidak disertai peningkatan PDW dan PCT. Nilai MPV dan PDW berkorelasi dengan kadar ureum kreatinin yang menunjukkan resiko ke arah gagal ginjal kronik.

\section{DAFTAR PUSTAKA}

1. Perhimpunan Dokter Spesialis Kardiovaskular Indonesia (PERKI). Pedoman tatalaksana hipertensi pada penyakit kardiovaskular. Edisi I. Jakarta: PERKI. 2015

2. Rilantono LI. Penyakit kardiovaskular. Fakultas Kedokteran Universitas Indonesia: Jakarta. 2016

3. Mohammad Y. Pendekatan klinis hipertensi. Dalam: Buku Ajar Ilmu Penyakit Dalam. Edisi VI. Jakarta. Interna Publishing. 2015. Hal 2259-83

4. World Health Organization (WHO). Calls for intensiified efforts to prevent and control hypertension. 2013 Available From: URL Hiperlink: http:// www.who.int/ workforcealiance/ media/ news/.

5. Badan Penelitian dan Pengembangan Kesehatan Kementrian Kesehatan RI. Riset kesehatan dasar (riskesdas). 2013. Available From: URL Hiperlink: http://www.litbang.depkes.go.id/sites/do wnload/rkd2013/Laporan_Riskesdas2013

6. James PA, Oparil S, Carter BI. Evidencebased guideline for the management of high blood pressure in adults: Report from the panel members appointed to the eighth Joint National Committee(JNC8). 2014.

7. National Center for Health Statistic. National health and nutrition examination survey (NHANES). December 2017. Available From: URL Hiperlink: https://www.cdc.gov/nchs/data/factsheet/ factsheet_nhanes.pdf

8. Osuji CU, Nwaneli, Onwubere BJ, Onwubuya EI, Ahaneku GI. Renal function in patients with hypertension associated congestive cardiac failure seen in a tertiary hospital. Int $J$ Nephrol. 2012:1-5.

9. McLaughlin K, Zhang J, Lye SJ, Parker JD, Kingdom JC. Phenotypes of pregnant women who subsequently develop hypertension in pregnancy. Journal of the American Heart Association. 2018;7(14), e009595.

10. Surgit O, Pusuroglu H, Erturk M. Assessment of mean platelet volume in patients with resistant hypertension, controlled hypertension and normotensives. Eurasian $\mathrm{J} \mathrm{Med}$. 2015;47(2):79-84.

11. Kocyigit I, Eroglu E, Unal A, Sipahioglu $\mathrm{MH}$, Tokgoz B, Oymak O,et al. Role of neutrophil/lymphocyte ratio in prediction of disease progression in patients with stage-4 chronic kidney disease. Journal Nephrology. 2013;26(02):358-365.

12. Basant J, Sageeta S, Suman P. A study of serum urea, creatinine and proteinuria in hypertensive patients. International Journal of Current Research. 2016;8(10):40295-40299.

13. Kusumawaty J, Hidayat N, Ginanjar E. Hubungan jenis kelamin dan hipertensi pada lansia di wilayah kerja Puskesmas Lakbok Kabupaten Ciamis. Mutiara Medika. 2016;16(2):46-51.

14. Surgit O, Pusuroglu H, Erturk M. Assessment of mean platelet volume in patients with resistant hypertension, controlled hypertension and normotensives. Eurasian J Med. 2015; 47:79-84.

15. Giovanetti TV, do Nascimento AJ, de Paula JP. Platelet indices: laboratory and clinical applications. Rev Bras Hematol Hemoter. 2011;33:164-165

16. Yang K, Lixin T, Gehendra M, Yan Y, Cao K. An association of platelet indices with blood pressure in Beijing adults, Applying quadratic inference function for a longitudinal study. Medicine (Baltimore). 2016;95(39): e4964. 